\title{
USE OF HOT AIR ENGINE TO GENERATE ELECTRICITY FROM BIOGAS: A CRITIQUE FOR RURAL DEVELOPMENT IN TANZANIA
}

\author{
LLN Mkiramweni ${ }^{1}$, P Msaki $^{1}$, IB Mshoro ${ }^{2}$ \\ ${ }^{1}$ Physics Department, University of Dar es Salaam, \\ P. O. Box 35063, Dar es Salaam, \\ ${ }^{2}$ Department of Design and Production Engineering University of Dar es Salaam, \\ P. O. Box 35131, Dar es Salaam.
}

\begin{abstract}
Rural electrification has high national priority because of several reasons. First, more than 90 per cent of the populations in Tanzania have no access to grid electricity and about $80 \%$ of this population lives in rural areas. Second, the poverty alleviation projects demand the incorporation of use of electricity in different economic projects. Third, a combination of high prices of fuel and environmental degradation and deforestation demand use of alternative renewable energy sources. The aim of this paper is to give a critical review and selected a suitable renewable energy by considering its ability to provide affordable, reliable and adequate electricity to household, energy-intensive agriculture and small businesses. Hot air engine designed to convert chemical energy of biogas to electricity was considered to be the most suitable technology for this purpose. In view of this, the paper has also described the technical constraints that prevent this technology from being adopted for this purpose and the alternative solutions that can be used to overcome them. It was concluded that it is possible to modify and produce a hot air engine that uses biogas, which produces sufficient and affordable electricity in rural communities in Tanzania.
\end{abstract}

\section{INTRODUCTION}

There is overwhelming evidence that supports energy consumption per capita as a good indicator of national development. For example, electricity consumption per capita in Tanzania is $60 \mathrm{kWh}$ which is less developed than Kenya (127 kWh) and underdeveloped when compared to Sweden with significantly higher $(15,000 \mathrm{kWh})$ energy consumption per capita (Wano 1997). Less than 10 per cent of the population in Tanzania has access to the grid and about $80 \%$ of the population live in rural areas where their energy requirements are mostly met by firewood. The government energy policy is aimed at increasing the access of the population to electricity and improving availability and quality of power supply (Saleh, 2002). However, attempts to implement this plan are frustrated by a combination of high transmission costs and low electricity consumption rates in the rural area (Msaki 2001).
However, rural electrification is now an essential element for rural development for several reasons. First, about $80 \%$ of the population lives in the rural areas where energy requirements are mostly met by wood fuel, resulting in deforestation and substantial environmental degradation. It is becoming apparent that supply of fuel wood is decreasing very rapidly therefore there is a great need to look for other alternative sources of energy. Second, the poverty alleviation projects in the country demand the incorporation of use of electricity in different economic project including intensive agriculture and business in the rural areas. Third, a combination of high prices of fuel and environmental degradation and deforestation demand use of alternative renewable energy sources. Fourth, the current economic reform in the country requires the citizen to start small and medium industries not only in towns but also in rural areas. Therefore, deliberate efforts are now being made to incorporate 
energy needs of the agricultural sector, in poverty alleviation projects (Mrindoko \& Mwihava 2000).

\section{ENERGY STATUS IN RURAL AREAS Energy Demand in Rural Areas}

The electricity utilization desired in the rural area can be classified in three categories. The first is a standalone power system exclusively designed to supply electricity to household. Assuming the house has as a radio, music system, two refrigerators, water heater, pressing iron and electric stove. Table 1 shows the power required to meet these appliances.

Table 1: Description of three classes of systems in a modern rural area in Tanzania and their power requirements

\begin{tabular}{clc}
\hline $\begin{array}{c}\text { Classification of } \\
\text { Electricity Need }\end{array}$ & \multicolumn{1}{c}{ List of Component in Need of Electricity } & Power Requirement (kW) \\
\hline Household & Cooking & 3 \\
& Lighting & 1 \\
& Others; radio, TV, iron, Refrigerators , water & 2 \\
& heater & 6 \\
Farming & As obove & 10 \\
& Intensive faming systems & 15 \\
Business & Commercial enterprising systems & $30-60$ \\
& Commercial Supply about 5 to 10 houses & $30-60$ \\
\hline
\end{tabular}

The second is also standalone power system to supply electricity to a household (described above) and energy-intensive farming systems (e.g. water pump, drying) or energy-intensive commercial enterprising systems based on lumber, grinding, refrigeration and brick making or remote communications. The third is a combination of standalone systems designed to provide power to a small village with 10 40 households by independent power providers (IPP) in the rural sector. The items that will need power in each category and an estimate of amount needed have been presented in Table 1. The paper has three objectives: The first is to provide a critical analysis of potential renewable energy technologies that can be used to deliver the power needed to these categories. The second is to provide a critique of the limitations of engines that can be used to provide the power needed for these purposes. The third and most important is to provide detailed description of the features design and construction that currently make the hot air engine unable to meet these energy demands despite its known potential.

\section{Energy Supply in Rural Areas}

Currently renewable energies such as solar, wind and biogas can be harnessed for rural applications in Tanzania. For example in rural China Photovoltaic (PV) of about 60 $\mathrm{W}$ to $120 \mathrm{~W}$ and $\mathrm{PV} /$ wind hybrids of about $60 \mathrm{~W}$ to $300 \mathrm{~W}$ have been shown to provide an economic option for meeting energy needs for households (Byrne et al. 1998). Already we are witnessing PV installation in Tanzania of capacity $0.550 \mathrm{MW}$ with an annual growth rate of about $20 \%$ (Mwihava 2002). Although the $20 \%$ growth rate is quite impressive, this value could be even higher if the associated technology had lower initial costs, less technological sophistication and few imported components. According to Table 2, this technology has high initial costs and its installation relies exclusively on imported components. According to this table, the technology in this price range can hardly satisfy the energy-intensive agricultural inputs such as pumping water for irrigation, cooking, refrigeration, lumber mills etc. Unavailability of energy at night is an additional limitation that makes this 
alternative less attractive to rural dwellers in

commercial purposes.

need of electricity for cookers and

Table 2: $\quad$ The cost of installation of photovoltaic system designed to perform specific household tasks

\begin{tabular}{lcc}
\hline Items powered by solar energy & Power (W) & Costs Tshs \\
\hline Four lighting system and radio & 40 & $717,000 /=$ \\
Six lighting system and radio & 60 & $1,094,000 /=$ \\
Six lighting system, TV, deck and music system & 150 & $2,769,000 /=$ \\
Eight lighting system, TV, deck and music system & 180 & $3,094,000 /=$ \\
\hline
\end{tabular}

Source (Solar energy contractors 2001)

Based on the available information much of the wind resource in Tanzania is located along the coastline, the highland plateau regions of the rift valley, on the plains and around the great lakes (Mwihava 2002). For example wind turbines of about $100 \mathrm{~W}$ to $300 \mathrm{~W}$ have also been found feasible in China, Europe and the U.S.A. (Byrne et al. 1998). Wind energy $(100 \mathrm{~W}-300 \mathrm{~W})$ with its high initial cost and imported materials can as well be developed to supply the rural population with the electricity they need for their households. However this technology cannot meet the energy-intensive requirement such as farming and running small business. But engine running with biogas can supply electricity sufficient for the above items.

\section{ENGINES FOR BIOGAS}

\section{Internal Combustion Engine}

Already there are types of internal combustion engine that has been modified to use biogas as fuel (Klaus 1988, Huang \& Crookers 1998, Henham \& Makkar 1998 among others). Such engines can supply a household with electricity comparable to that from standard diesel engines. In this case the engine can satisfies the energyintensive agricultural inputs requirements required in the rural area. The initial costs of one unit of about $800,000 /=$ to $1,200,000 /=$ which can produce about 50 $\mathrm{kW}$ is less expensive than that required to purchase PV technology. The biogas technology is also familiar because there are many rural farmers already using biogas for cooling and lighting houses so these farmers would be more than eager to have electricity out of such a familiar and cheap product.

There are two major drawbacks of this technology. The first is that the engine has high noise pollution. The second is such modified diesel engines are imported and local modification of existing diesel engines would require permission from the manufacturer. Designing and constructing a hot air engine that is an external combustion engine can overcome these drawbacks.

\section{Hot Air Engine}

There are three types of hot air engine i.e. Alpha, Beta and Gamma arrangements (Kirkley, 1962). These types of engines have certain parts with common function, but for the purpose of this paper the losses resulting from the regenerator, which is used to store heat energy during parts of the cycle and return it to the working gas during the other part, will be discussed. Fig. 1 shows the alpha engine configuration with regenerator divided into three cells. The effectiveness, $\varepsilon$ of a regenerator requires the following quality such as maximum heat transfer and heat storage capacity materials; with minimum pressure drop and dead space. These qualities are interrelated in conflicting way so optimization is required for smooth operation of the hot air engine. The effectiveness of the regenerator depends on the low temperature difference between the gas and the matrix, but this also lead to a relative high-pressure drop. It also depends on the rate of storing heat during one cycle 
and releasing heat stored during the other cycle. Fig. 2 shows the flow of the working gas from the cooler to the heater of the engine whereby the matrix of the regenerator is supplying heat to the working gas. The following are types of losses associated with the regenerator of the hot air engine. Fig. 3 shows the losses of the regenerator of the hot air engine as simulated using SNAP 2002 program.

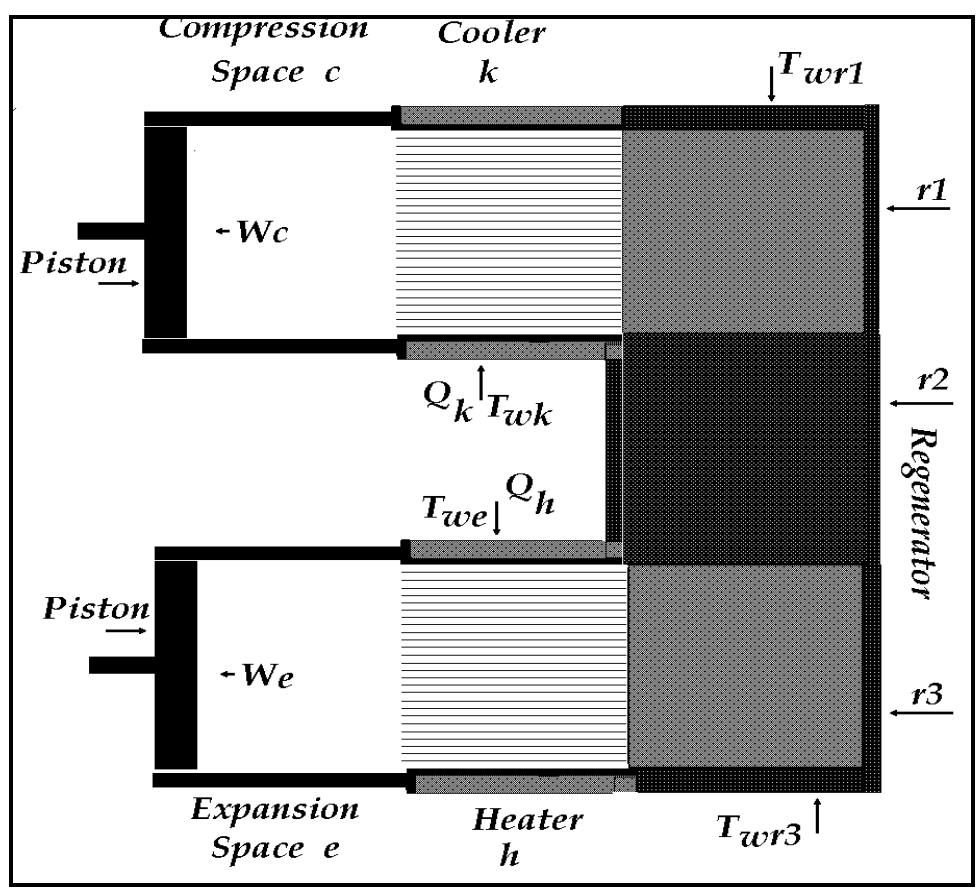

Figure 1: Alpha Configuration Engine.

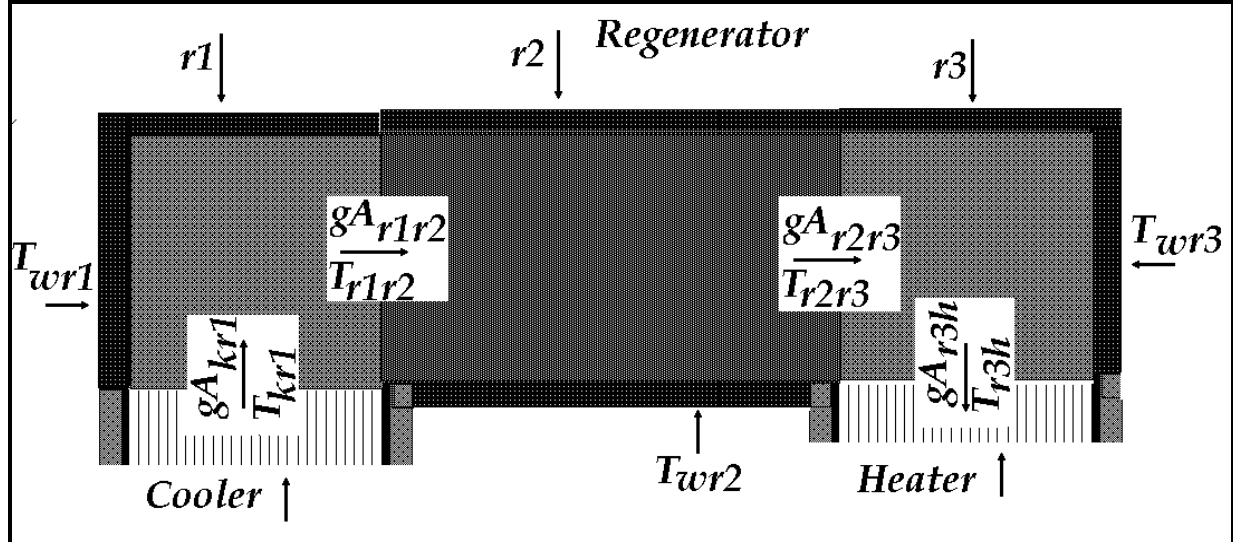

Figure 2: $\quad$ Mass Flow in the Regenerator. 


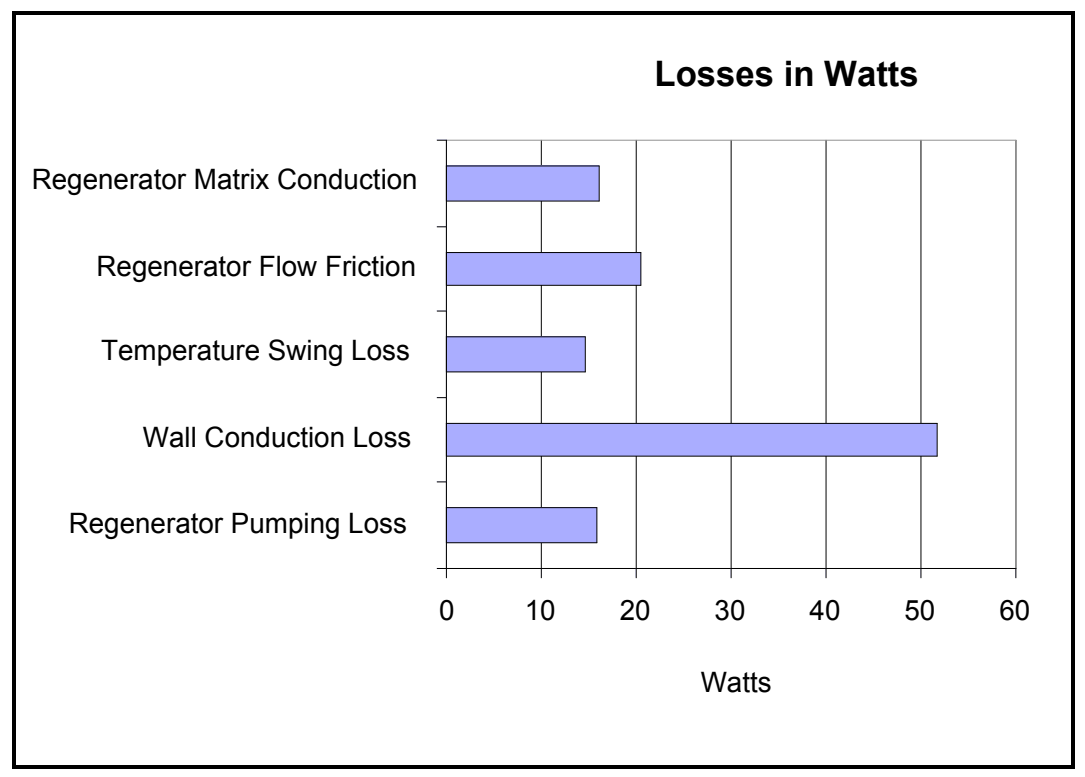

Figure 3: Losses of the Regenerator of the Hot Air Engine.

\section{Regenerator Pumping Loss}

The pumping loss results from the matrix inside the engine. The increase in heat transfer capacity result in increase of pumping loss. Under pumping loss the cylindrical ducts $C_{f} L / r_{h}$ has a value close to 3.7NTU (Kayas and London, 1964) the expression required can be expressed as:

$\varsigma_{p l}=3.7 \pi \sigma^{\prime 3} N T U \frac{T_{E}}{T_{C}} \frac{N_{M A}^{2}}{a_{f f}^{2}} \frac{1}{\psi^{2}}$

In equation (1) the pumping loss is inversely proportional to the square of the dimensionless pressure $\mathrm{pV}_{\mathrm{rec}} /\left(\mathrm{MRT}_{\mathrm{re}}\right)$. The compromise must be reached in material selection because the loss is the penalty on efficiency and the specific power of the engine.

\section{Wall Conduction Losses}

The conduction loss is the result of the good conductor materials used to construct an engine. The loss will also depend on the size of the cell used and temperature gradient. The regenerator is divided into three cells $r_{1}, r_{2}$ and $r_{3}$, each cell being associated with its respective mixed mean gas temperature $T_{r 1}, T_{r 2}$, and $T_{r 3}$ and corresponding effective bulk matrix temperature $\mathrm{T}_{\mathrm{wr} 1}, \quad \mathrm{~T}_{\mathrm{wr} 2}$ and $\mathrm{T}_{\mathrm{wr} 3}$. The regenerator interface temperature $T_{\mathrm{r} l k}, T_{\mathrm{rl} r 2}$, $\mathrm{T}_{\mathrm{r} 2 \mathrm{r} 3}$ and $\mathrm{T}_{\mathrm{r} 3 \mathrm{~h}}$ are as follows:

$$
\begin{aligned}
& \mathrm{T}_{\mathrm{kr} 1}=\left(3 \mathrm{~T}_{\mathrm{r} 1}-\mathrm{T}_{\mathrm{r} 2}\right) / 2 \\
& \mathrm{~T}_{\mathrm{r} 1 \mathrm{r} 2}=\left(\mathrm{T}_{\mathrm{r} 2}-\mathrm{T}_{\mathrm{r} 1}\right) / 2 \\
& \mathrm{~T}_{\mathrm{r} 2 \mathrm{r} 3}=\left(\mathrm{T}_{\mathrm{r} 3}-\mathrm{T}_{\mathrm{r} 2}\right) / 2 \\
& \mathrm{~T}_{\mathrm{r} 3 \mathrm{~h}}=\left(3 \mathrm{~T}_{\mathrm{r} 2}-\mathrm{T}_{\mathrm{r} 1}\right) / 2
\end{aligned}
$$

This type of loss will be considered during simulation and during designing. The possible conduction path within the space of a cell in the simulation will be included. The rate of heat transfer per second is given by:

$$
\frac{d Q}{d t}=k \pi\left(\frac{D_{o}^{2}-D_{i}^{2}}{4}\right)\left(\frac{T_{w i}-T_{w o}}{W_{t h}}\right)
$$

Conduction loss can affect the efficiency of the machine more than the working gas temperature especially a big size cell with high temperature difference. Lagging the regenerator will reduce this loss because the heat energy inside it is supposed to be maintained. 


\section{Temperature Swing Loss}

The entropy creation rate per unit mass, $s^{1}$ when heat flows at rate $\mathrm{q}^{1}$ per unit mass across temperature difference of $\Delta \mathrm{T}$ at the gas temperature $T_{g}$ is given by $s^{1}=q^{1} \Delta T / T_{g}^{2}$. (Bejan, 1982). The temperature swing loss resulting from entropy creation is given by:

$$
s^{1}=\frac{Q\left(T_{g}-T_{w}\right)}{\rho A_{f f} L_{r e g} T_{g}^{2}}
$$

Entropy creation rate per unit mass depends on the geometry of the regenerator and temperature difference between the working gas and the materials used of any cell of the system.

\section{Gas Flow Friction}

Entropy transfer and entropy creation depends on the variation of the pressure and temperature of the systems. The rate of entropy creation is due to wall and wire mesh friction. The governing equation is given by:

$$
\varsigma_{f f}=10.0 \sigma^{\prime} \frac{N_{s t} L_{r e g}}{r_{h}} \frac{1}{\tau_{w}} \frac{N_{M A}^{2}}{a_{f f}^{2}} \frac{1}{\psi^{2}} \phi
$$

The left hand side of equation (8) is normalized by $\mathrm{MRT}_{\mathrm{o}}$ abbreviated to $\mathrm{S}_{\mathrm{ff}}$ and the expression $\mathrm{C} / \mathrm{N}_{\mathrm{st}}$ is replaced by 10.0 for the wire mesh. The heat stored in the regenerator exchange has large effect to the power generation of the machine. But increased regenerator matrix /mesh cause much flow loss. So, the relations need more investigation.

\section{Regenerator Matrix Heat Transfer}

The heat flows at the rate q' per unit mass is proportion to the entropy creation over an elemental length of the duct $\mathrm{dx}$, and reducing to the base of $n_{s} M_{R} T_{c}$ (per cycle per unit mass) is given by;

$$
\varsigma_{m q}=\frac{\gamma-1}{\gamma} \frac{1}{4 \pi \sigma^{1}}\left\{\frac{\Psi N_{B} N_{T}}{\tau_{m t x}\left(N_{T}-1\right)}\right\}^{2} \frac{1+e^{-N T U}}{1-e^{-N T U}}
$$

In this expression the NTU is determined for the work loss using length ratio. The loss increases with the size of the cell under consideration. For the regenerator it is evaluated according to location $(\lambda=\mathrm{x} / \mathrm{L})$ in an integration with respect to $\mathrm{t}$ along the particle path.

\section{Optimized Flow Model}

Optimized flow model solve homogeneous equations of flow and losses of hot air engine. The major difference between the optimized flow model and the Quasi Steady flow model is the heat exchanger section. The regenerators is divided into three cells each cell being associated with mixed mean gas temperature and corresponding effective matrix temperature. The continuity equation is used to evaluate the mass flow $g \mathrm{~A}$ shown in Fig. 2. 


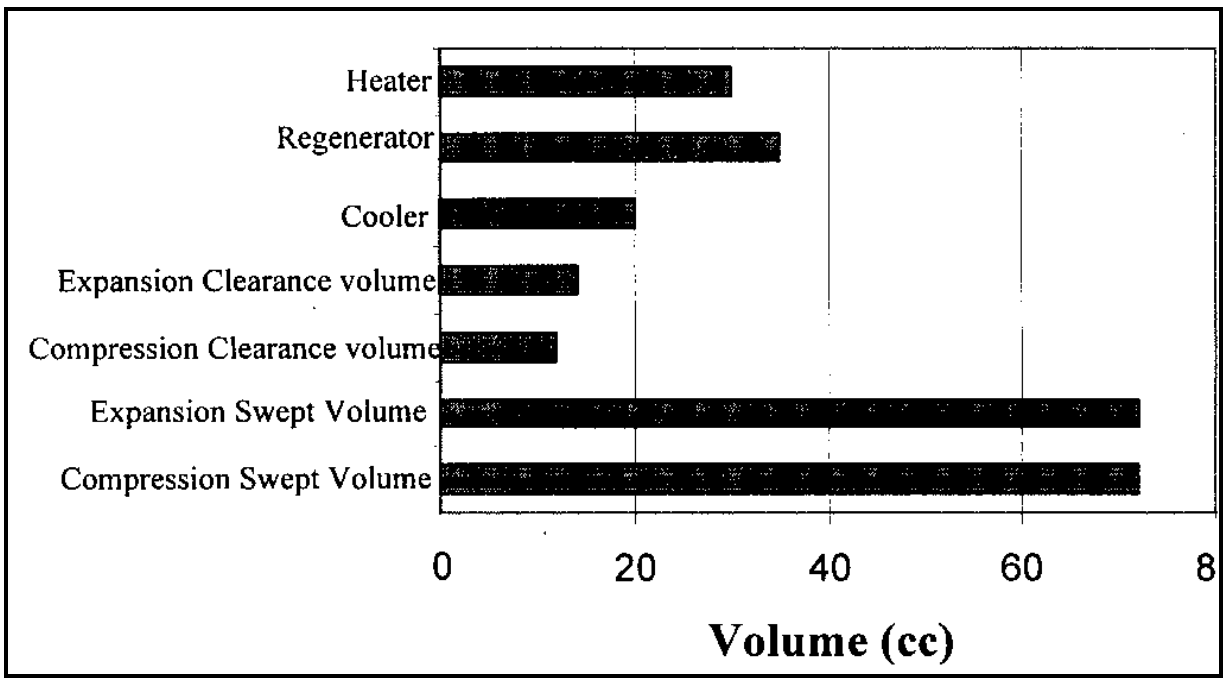

Figure 4: Volume variation in the hot air engine.

The mass flow equation in the regenerator is given by;

$$
\begin{aligned}
\mathrm{Dm}_{\mathrm{r} 1} & =\mathrm{gA}_{\mathrm{kr}}-\mathrm{gA}_{\mathrm{rr} 1} \\
\mathrm{Dm}_{\mathrm{r} 2} & =\mathrm{gA}_{\mathrm{rr} 1}-\mathrm{gA}_{\mathrm{rr} 2} . \\
\mathrm{Dm}_{\mathrm{r} 3} & =\mathrm{gA}_{\mathrm{rr} 2}-\mathrm{gA}_{\mathrm{rh}}
\end{aligned}
$$

The general approach is to apply the equations of energy and state to each of the cells, which are considered as control volumes. The energy equation, which includes flow dissipation effects and the mathematically word statement are the same as the of Quasi steady flow model.

$$
\begin{aligned}
& {\left[\begin{array}{l}
\text { rate of heat transfer } \\
\text { into the cell }
\end{array}\right]-\left[\begin{array}{l}
\text { rate of heat generation } \\
\text { due to flow disspation }
\end{array}\right.} \\
& {\left[\begin{array}{l}
\text { rate of work done } \\
\text { on the surrounding }
\end{array}\right]+\left[\begin{array}{l}
\text { rate of increase of } \\
\text { internal energy in the cell }
\end{array}\right]}
\end{aligned}
$$

Mathematically the word statement becomes

$$
\mathrm{DQ}-\mathrm{DpgA} / \rho+\left(\mathrm{C}_{\mathrm{p}} \mathrm{T}_{\mathrm{i}} \mathrm{gA} \mathrm{A}_{\mathrm{i}}-\mathrm{C}_{\mathrm{p}} \mathrm{T}_{\mathrm{o}} \mathrm{gA}\right)=\mathrm{PdV}+\mathrm{C}_{\mathrm{v}} \mathrm{D}(\mathrm{mT})
$$

This equation can be used to evaluate the heat transfer and energy in the individual cell as shown in Fig. 1 and Fig. 4 of the alpha configuration of the hot air engine. Particularly, by using volume variation techniques. Fig. 4 shows the relationship between the volume of the engine and that of individual cell.

\section{CONCLUSION AND}

\section{RECOMMENDATION}

About $80 \%$ of the populations in Tanzania live in rural areas where firewood is they are major source of energy. Only 6\% of the energy supply is in a form of electricity, which is flexible form to use for household and economic activities. There is a great need to increase this form of energy particularly in the rural area. Three renewable sources of energy (solar, wind and biogas) 
that could be used to supplement hydropower were examined. Biogas was found to be more suitable in terms of low initial cost, familiarity, availability and other tangible benefits. At present only a very small amount of biogas is available in form of electricity using internal combustion engines. Noise pollution, technical sophistication and patents are the three major drawbacks that make widespread use of this technology unattractive. The main parts of the hot air engine, basic equation that governs its operation and the losses due to the regenerator which affect the power output and efficiency were also presented. The general equation that governs the performance of each cell of the hot air engine will later be used to analyse the performance of the cell.

Biogas technology is important but it cannot be practiced without conducting research in order to optimize its usefulness in Tanzania. For effective development of the technology, the current status of biogas in the country must first be investigated for further development.

\section{Nomenclature}

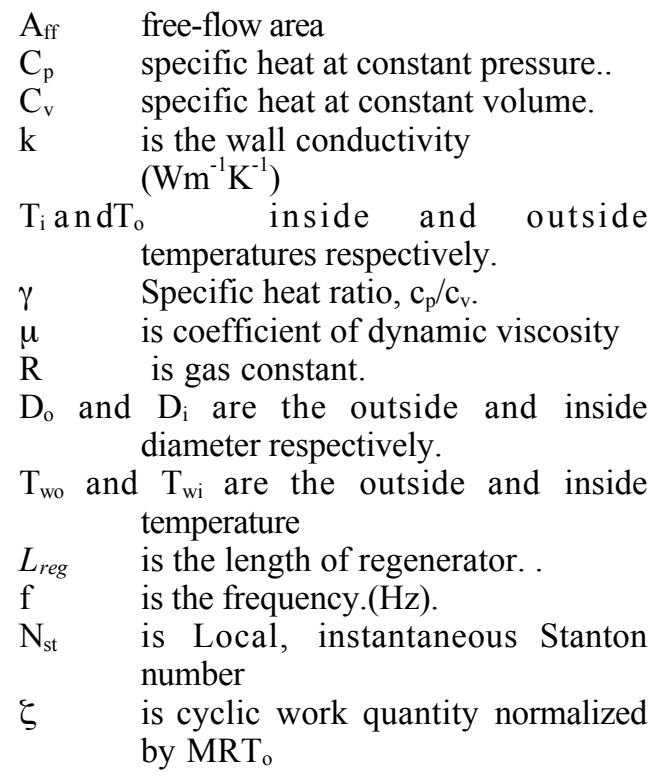

$\sigma \quad$ Dimensionless mass

$\tau \quad$ Dimensionless temperature, $\mathrm{T} / \mathrm{T}_{\text {ref. }}$.

$\mathrm{N}_{\mathrm{B}} \quad$ Beale number.

$\mathrm{N}_{\mathrm{MA}}$ is the characteristic speed parameter.

$\mathrm{N}_{\mathrm{T}} \quad$ Characteristics temperature ration.

$\phi \quad$ is crank angle.

NTU is number of transfer units.

A is wetted radius of cylindrical duct.

$\psi \quad$ is dimensionless pressure

$\mathrm{r}_{\mathrm{h}} \quad$ Hydraulic radius

$\mathrm{W}_{\text {th }} \quad$ wall thickness of the regenerator

\section{REFERENCES}

Bejan A 1982 Entropy generation through heat and fluid flow. John Wiley, New York, USA.

Byrne J, Shen B and Willace W 1998 The economics of sustainable energy to rural development: A study of renewable energy rural China. Energy Policy, 26(1):pp 45-54 also available at website:

http://www.nrel.gov/international/china/ pdfs/ (visited on April, 2004)

Henham A and Makkar MK 1998 Combustion of Simulated Biogas in a dual-fuel diesel engine. Energy Conversion and Management, Vol.39, Number16/18. pp 2001-2009

Huang J and Crookers RJ 1998 Sparkignition engine performance with simulated biogas-a comparison with gasoline and natural gas. Journal Institute of Energy. Issue 489 pp 197203

Kayas WM and London AL 1964 Compact heat exchangers second edition, McGraw Hill, New York, USA.

Klaus von Mitzlaff 1988 Biogas for Engine. Theory, Modification, Economic Operation. A Publication of Deutsches Zentrum fur Entwicklungstechnologien -GATE

Kirkley DW 1962 Determination of the Optimimum Configuration for a Stirling Engine. J. Mech. Engineering Science, Vol 4, pp 204-212

Mwihava NCX and Mrindoko BJ 2000 The Status of Renewable Energy Application in Tanzania. Paper presented at the 
OAU/STRC Experts Meeting on Renewable energies, IPI University of Dar es Salaam $20^{\text {th }}-24^{\text {th }}$ March 2000.

Msaki P 2001 Methods to Generate Environmental Knowledge, Techniques And Partnership With Business In Tanzania. Sustainable Development International.

Organ AJ 1997 The Regenerator and the Stirling Engine. Mechanical Engineering Publications Limited London and Bury St Edmunds, UK

Saleh M 1999 Tanzania Electricity Supply Industry Trends E.S.I. Africa 22002

Sustainable Business 1998 Economic Development and Environmentally
Sound Technologies. UNEP Report and Regency Corporation Limited.

Urieli I and Berchowitz DM 1984 Stirling Cycle Engine Analysis. Adam Hilger book-publishing is owned by the Institute of physics, Ltd Bristol.

Wano 1997 The Case for Nuclear Power. Opening Session, Fifth Biennial General Meeting of the World Association of Nuclear Operators 12 May 1997 Prague, Czech Republic

http://www.iaea.or.at/worldatom/Press/S tatements/FormerDG/dgsp1997n04.html (visited on April 2004). 